\title{
Semiotic Approach on Artist's Brand Communication: The Case of Damien Hirst
}

\author{
Jin Woo Lee, Shin Eui Park \\ Graduate School of Business Administration, Kyung Hee University, Seoul, Korea
}

Objectives: This paper aims to argue how the structure of brand communication by artists creates value in the art market. Artists have already made brands of themselves through self-promotion, networking with stakeholders in the art world, and other activities, and the effects of the artist's brand communication vary depending on the process used.

Methods: We select Damien Hirst as a single case, and secondary data from various sources are collected. We analyze the gathered data in order to understand the brand of Hirst in terms of general branding theory and art institution theory.

Results: The semantic approach starts with the assumption that Hirst's brand consists of what Saussure calls a 'significant' and a 'signifié.' The significant involves the ostensible brand revealed in the bizarre and shocking, self-promotion, anti-institutional norms, blasphemy of art, etc., but the hidden symbol, signifié, was created by the existence of Charles Saatchi, a renowned collector, and it involves the symbolic power of YBA and the logic of the art market.

Conclusions: The analysis of Hirst's brand, however, shows a paradoxical result. Although his powerful brand was constructed by subverting and challenging the institutional system of art, the system embraces his works, which is shown in the high economic value it brings in the art market. Thus, a differentiation strategy is possible in internal contradictions.

Key Words: Artists’ Brands, Brand Identity, The Art World, Damien Hirst, Symbolic Power

\section{Introduction}

Brand is an inevitable term in the contemporary art market because it is hard to decide the worth of contemporary art - visual works of art from 1970 to present day - by aesthetic standards. In other words, there are traditional approaches when it comes

Received: Oct 3, 2018 Revised: Dec 3, 2018 Accepted: Dec 14, 2018 Corresponding author: Shin Eui Park

Department of Arts and Cultural Management, Graduate School of Business Administration, Kyung Hee University, 26 Kyungheedae-ro, Dongdaemun-gu, Seoul 02447, Korea

Tel: +82-2-961-9211, E-mail: lunapark@khu.ac.kr

This is an Open Access article distributed under the terms of the Creative Commons Attribution Non-Commercial License (http://creativecommons.org/licenses/ by-nc/4.0/) which permits unrestricted non-commercial use, distribution, and reproduction in any medium, provided the original work is properly cited.

Copyright $(\odot) 2019$ Korean Association for Business Communication. to evaluating artworks: aesthetic quality, size, material, and when the artwork was produced. However, contemporary art is hard to value objectively in terms of only aesthetic qualities (Peterson, 1997) as contemporary artists intentionally ignore the appearance of their artworks, placing an emphasis instead on their conception (Danto, 1997). Then, the key feature in the contemporary art market, the uncertain value of goods (Samdanis \& Lee, 2019), leads collectors to rely more on "[the painting's] artist..., a painting that is owned by , handled by or hangs in " (Aaker, 2009, p. 14); brands have a great influence on the contemporary art market (Thompson, 2008).

Such importance of brands in practice has inspired recent scholars. On the one hand, while previous researchers have agreed on considering cultural institutions as brands, they have also highlighted the process of establishing brand image 
and the value of institutions such as museums (Caldwell, 2000; Camarero, Garrido-Samaniego, \& Vicente, 2012; Phillips \& O'Reilly, 2007). Reckoning with the fame of visual artists, on the other hand, branding theory has been applied into the following studies which examine the linkage between the context of art and branding by considering artists as brand managers (Muniz, Norris, \& Fine, 2014; Schroeder, 2005), the establishment of the brand narratives of artists (Preece \& Kerrigan, 2015; Rodner \& Kerrigan, 2014; Rodner \& Thomson, 2013), and the life and artworks of Andy Warhol (Hewer, Brownlie, \& Kerrigan, 2013; Kerrigan, Brownlie, Hewer, \& Daza-LeTouze, 2011) and Ai Weiwei (Preece, 2015) to elucidate celebrity brand and consumption.

Although these studies insightfully engage with the topic of artists' brands, there is little understanding of an artist's brand communication. We thus identify the following research question: How is an artist's brand communication constructed? By considering Damien Hirst as an instrumental case (Stake, 1994), this paper addresses the question with a focus on conceptualizing the brand of an artist, which leads us to provide conceptual directions for future research on contemporary artists and brands. In the following section, we will first delineate the life and artworks of Damien Hirst and discuss the similarity and difference of brand meanings between the general commercial market and the visual arts market. Then, this paper will conclude with an analysis of Hirst's brand by arguing a collision between the identity of the brand challenging institutions (visible image) and the one established by institutions (symbolic power).

\section{Case Description}

"Damien Hirst is at the top of the modern art food chain" (Jones, 2011).

According to the quotation above, Damien Hirst is one of the most influential artists in the current era. Since the beginning of his artistic career, Hirst has been involved in around 80 solo exhibitions and 260 group exhibitions globally, including a retrospective exhibition at the Tate Modern in 2012 (Hirst, n.d.). Hirst was born in 1965 in Bristol, UK and grew up in Leeds, where he explored the subject of death for his artworks by regularly visiting a medical school. After moving to London, he was awarded a BA in Fine Art at Goldsmiths College in 1989 where his "understanding of the distinction between painting and sculpture changed significantly". (Hirst, n.d., para. 4). Tutors at Goldsmiths helped the artist develop the artistic theme of his work. For instance, in his second year at art school, Hirst created one of his most important works of art, Medicine Cabinets.
In the same year, he organized and curated the Freeze exhibition with works of art by his peers, which has since been considered as engendering a new artistic group, known as, the 'Young British Artists' (YBAs) (Thompson, 2008).

At this influential exhibition, Hirst encountered Charles Saatchi, a renowned collector with a high reputation for his economic and social capital. After the meeting, Saatchi became a devoted supporter of Hirst. For instance, in 1991, he commissioned Hirst to produce a stuffed shark placed in a formaldehyde solution for $£ 50,000$, The Physical Impossibility of Death in the Mind of Someone Living (Figure 1), which sold for $\$ 12$ millon in 2004. Moreover, Saatchi is "a key part of Hirst's career, boosting him onto the international art market" (Preece, Kerrigan, \& O'Reilly, 2016, p. 1388). With his winning of the Turner Prize in 1995, his name inarguably became more well-known, and his work and actions began to have a significant impact on the public, generating a large volume of articles in the media. Reflecting his status in the contemporary art market, his work is sold at premium prices at auction houses. Before the age of 40, in 2005, Hirst had acquired more than \$1 million and sold approximately $\$ 270$ million worth of work at Christie’s in 2008 (Penet \& Lee, 2014).

Apart from creating works of art, Hirst has played multiple roles. According to Galenson (2009), Hirst has become known for his entrepreneurship. He established a web company, Other Criteria, which has sold a variety of artwork by several contemporary artists including Hirst's own. Moreover, the website has offered many kinds of products related to Hirst, such as T-shirts, pens, card holders, books, posters, key rings, umbrellas, and even guitars. ${ }^{1} \mathrm{He}$ also opened a restaurant, Pharmacy, in

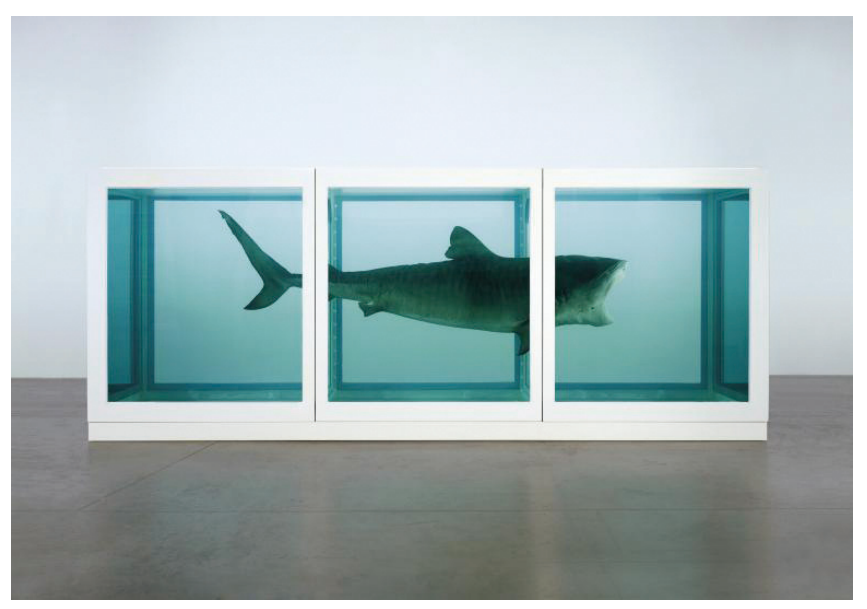

Figure 1. The Physical Impossibility of Death in the Mind of Someone Living (1991).

\footnotetext{
${ }^{1}$ The company has focused on publishing exclusive books and catalogues by several artists.
} 
which he displayed his work. Although the venue is now closed, it was patronized by many art experts and celebrities (Thompson, 2008). Additionally, Hirst is considered to be a major contemporary art collector. Thorpe (2012) reports that his personal collection consists of many contemporary artists' works, including works by Bacon, Koons, Lucas, and Banksy. With the opening of a new gallery in 2015, Newport Street Gallery, Hirst has shared his massive collection with a wider public.

\section{Discussion}

The concept of brand crosses over between the general commercial market and the visual arts market, which have two facets in common. Firstly, the outputs of producers are distinguished by brand. For instance, in the general market, the brand of a product plays a role in signposting standards and differences within a similar product category (Aaker, 1991). In a similar way, the brand of an artist acts as a crucial factor in distinguishing one work of art from others of a similar style (Schroeder, 2005). For instance, in 2007, writer AA Gill once attempted to sell an item in his art collection on consignment at Christie's auction house. The work of art was a painting of Joseph Stalin by an unknown artist, and Christie's refused the consignment as they do not deal with works of art presenting Hitler or Stalin. Gill then asked Hirst to paint a red spot on the portrait of Stalin, adding "[Hirst's] signature below the nose", and it fetched $£ 140,000$ in auction at Christie's (Thompson, 2008, p. 69).

Brand also influences purchase-decisions pertaining to the product. Brand recognition decreases perceived decision-making risks (functional, physical, financial, social, psychological and time risks) and encourages the consumer to purchase a product (Keller, 1998). Equivalently, branded actors "confer a guarantee on artworks, giving consumers a sense of security and sustainability in a market that is constantly in flux" (Rodner, Omar, \& Thomson, 2011, p. 320). In other words, a known brand instills trust and reduces risks when consuming - either buying or viewing - artworks.

In contrast to these similarities, there are broad distinctions between brands in the arts and general markets. The first difference involves perspectives on the usage of the 'brand' concept. Although the operation of brand theory is crucial in general marketing, using the term 'brand' is seen as too vulgar in the arts market (Rentschler, 2007; Sargeant, 1999), as there is a belief that the explicit utilization of the concept of 'brand' might negatively impact the perceived 'purity' of the arts. Secondly, an artist can be considered a brand manager for his/her brand whilst managing their career at the same time, thereby generating a 'multifaceted public identity that is distinct from a product brand' (Muniz et al., 2014, p. 69).

Lastly, although the visual artist is a central point in the arts market network (Jyrama \& Ayvari, 2010), differentiating an artist's brand from others in the market is not under their own control. Hirst uses dead animals as the material for his works of art. By establishing a distinctive artistic style, marketing researchers insist that Hirst built a new market; Hirst focused on new consumers who bought works of art for fun, status, or investment returns by identifying "the market opportunity first and then aligned his artistic concepts accordingly" (Reckhenrich, Anderson, \& Kupp, 2009, p. 45). However, we need to pay more attention to the process by which the artistic style of Hirst's works of art was established.

To explore such a process, we need to consider the unique characteristics of contemporary art. In general, the visual arts have a high level of uncertainty in terms of their value as there are no obvious and objective standards for valorizing them in the market (Alexander \& Bowler, 2014). In a similar line, Peterson (1997, p. 244) points out two issues with the value of the visual arts, "as symbolic commodities, the price of an art work is not commensurable to the cost of its production (labor and materials)...contemporary artists have made the questioning of artistic value and authorship central to the subject matter of their work". In other words, the valuation of contemporary visual arts becomes more difficult as the focus of artist intention shifts from tangible appearance to the intangible conception of artworks (Danto, 1997). In the case of Hirst's works of art using dead animals as mediums, we hardly appreciate or value it based on its beauty, which leads us to focus more on the concept.

Various intermediaries are involved in interpreting the concept of works of art. Put differently, the emphasis on the role of intermediaries in the contemporary art market originates from the inherent characteristic of works of art. In the sociology of art, Becker (1982, p. x) defines the art world as "the network of people whose cooperative activity, organized via their joint knowledge of conventional means of doing things, produces the kind of art works that [the] art world is noted for," insisting that "the distinction must lie not in the work but in the ability of an art world to accept it and its maker" (p. 226). Going back to our case, Rodner and Kerrigan (2014, p. 111) note that "[1]iaising with collector and art promoter Charles Saatchi and with Tate Gallery director and curator Nicholas Serota and working within a coherent network of likeminded peers, Hirst became and remained the predominant contemporary artist of the 1990s." Although Hirst creates works of art, the construction of aesthetic discourse about the works of art is made by intermediaries (or likeminded peers, in the above sentence) such as curators, critics, dealers, and media in the art world. 


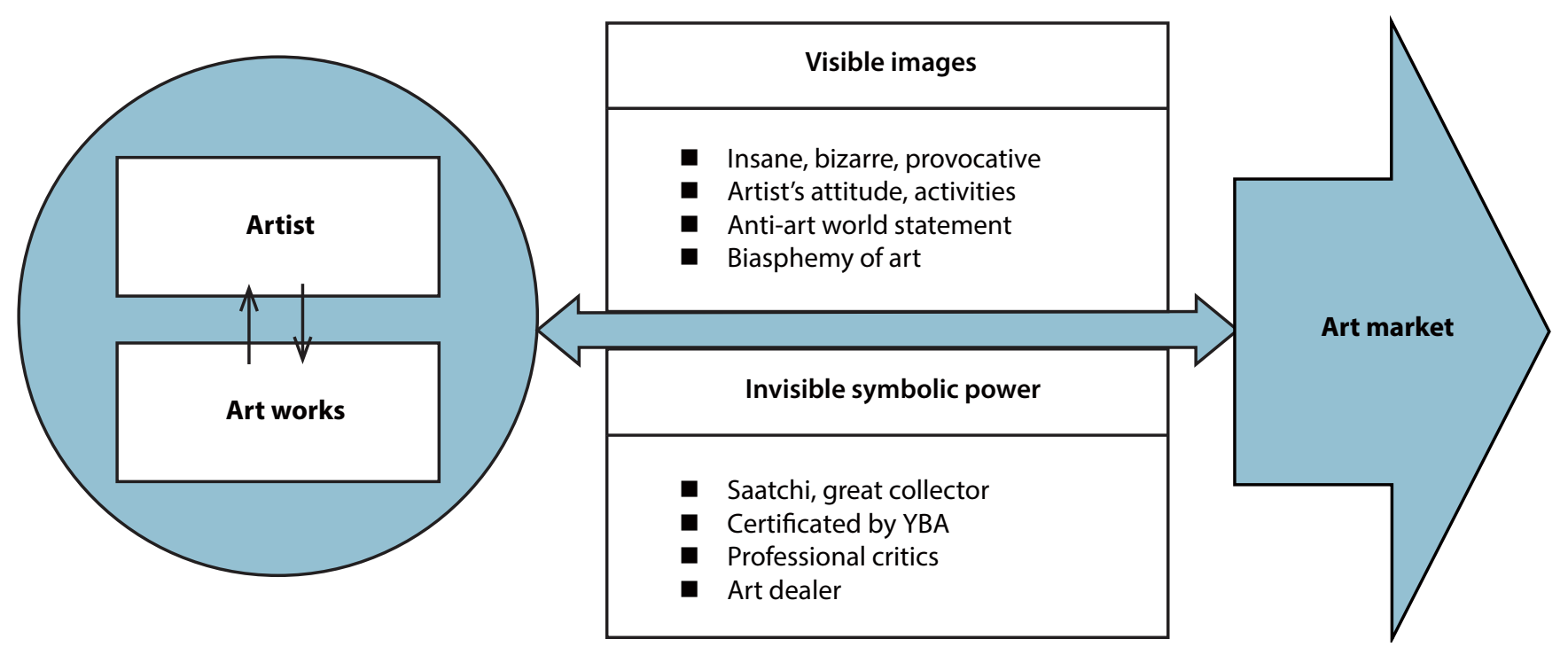

Figure 2. The structure of brand identity and influential relationship.

Furthermore, the success of Hirst is not independent from the social status of a renowned collector, Charles Saatchi. Bourdieu (1983) insists that the symbolic capital or reputation of each intermediary in the art world, the capital being accumulated by their economic and social capital, heavily impacts the construction of the discourse about the works of art. This is clearly shown in his later book, where he states: "[the artist is] offered as a guarantee all the symbolic capital the merchant has accumulated" (Bourdieu, 1996, p. 168). Thus, the fame of Saatchi in the art world unequally contributes to rendering the works of art by Hirst valid in the contemporary art market.

\section{Conclusion}

To summarize, there is no doubt that Damien Hirst is one of most influential artists in the contemporary art market, taking his artistic reputation and the price of his works of art into account. Consequently, people tend to consider the name of artists as global brands. Like brands in the market for mundane products, the brand of Hirst plays the role of decreasing risks and distinguishing the products (Keller, 1998) of his works of art from those of others as well as of helping consumers make a purchase decision (Aaker, 1996). However, conventional product brands are in a closed system while the arts are in an open system, creating, cajoling, confronting, and challenging (Butler, 2000).

Considering himself as a brand manager, Hirst has built his brand identity by promoting his insane, bizarre, and provocative attitude towards the institutional system of art and shocking the art world by producing unusual and blasphemous art.
This visible image of Hirst's brand contributes to generating the priciest artworks at auction houses. Put differently, such a challenge by Hirst against institutions in the art world paradoxically confer him a high reputation in the market. As we can see in Figure 2, the process of building Hirst's brand identity depends on understanding the invisible symbolic power of Saatchi, the certification of YBA, and several intermediaries (critics, media, dealers, and curators). This paper attempts to understand artists' brand at a societal level and shows the significant influence of institutional structure, namely the art world, upon artist's brand communication, which suggests insightful lessons for marketing scholars in line with the following research (J. W. Lee \& Lee, 2017; S. H. Lee \& Lee, 2016; Preece \& Kerrigan, 2015; Preece et al., 2016; Rodner \& Kerrigan, 2014; Rodner \& Preece, 2015). To extend this line of research, further research could explore the way in which consumers understand the visible and invisible image of artists' brands according to their level of consumption (e.g., appreciation or possession).

\section{References}

Aaker, D. A. (1991). Managing brand equity: capitalizing on the value of a brand name. New York, NY: Free Press.

Aaker, D. A. (1996). Building strong brands. London, UK: Simon and Schuster.

Aaker, D. A. (2009). Branding and contemporary art. Marketing News, 43(19), 14.

Alexander, V. D., \& Bowler, A. E. (2014). Art at the crossroads: The arts in society and the sociology of art. Poetics, 43(1), 1-19.

Becker, H. S. (1982). Art worlds. Berkeley, CA: University of Cali- 
fornia Press.

Bourdieu, P. (1983). The field of cultural production, or: The economic world reversed. Poetics, 12(4-5), 311-356.

Bourdieu, P. (1996). The rules of art: Genesis and structure of the literary field. Stanford, CA: Stanford University Press.

Butler, P. (2000). By popular demand: marketing the arts. Journal of Marketing Management, 16(4), 343-364.

Caldwell, N. G. (2000). The emergence of museum brands. International Journal of Arts Management, 2(3), 28-34.

Camarero, C., Garrido-Samaniego, M. J., \& Vicente, E. (2012). Determinants of brand equity in cultural organizations: The case of an art exhibition. The Service Industries Journal, 32(9), 1527-1549.

Danto, A. C. (1997). After the end of art: Contemporary art and the pale of history. Princeton, NJ: Princeton University Press.

Galenson, D. W. (2009). Conceptual revolutions in twentieth-century art. New York, NY: Cambridge University Press.

Hewer, P., Brownlie, D., \& Kerrigan, F. (2013). 'The exploding plastic inevitable': 'Branding being', brand Warhol \& the factory years. Scandinavian Journal of Management, 29(2), 184-193.

Hirst, D. (n.d.). Biography: Damien hirst. Retrieved from http:// damienhirst.com/biography/damien-hirst

Jones, J. (2011). Damien Hirst is at the top of the modern art food chain. The Guardian. Retrieved from https://www.theguardian. com/artanddesign/jonathanjonesblog/2011/nov/24/damienhirst-modern-art-tate

Jyrama, A., \& Ayvari, A. (2010). Marketing contemporary visual art. Marketing Intelligence \& Planning, 28(6), 723-735.

Keller, K. L. (1998). Strategic brand management: Building, measuring, and managing brand equity (Vol. 1). Upper Saddle River, NJ: Prentice Hall.

Kerrigan, F., Brownlie, D., Hewer, P., \& Daza-LeTouze, C. (2011). 'Spinning' Warhol: Celebrity brand theoretics and the logic of the celebrity brand. Journal of Marketing Management, 27(13-14), 1504-1524.

Lee, J. W., \& Lee, S. H. (2017). "Marketing from the art world": A critical review of American research in arts marketing. The Journal of Arts Management, Law, and Society, 47(1), 17-33.

Lee, S. H., \& Lee, J. W. (2016). Art fairs as a medium for branding young and emerging artists: The case of frieze London. The Journal of Arts Management, Law, and Society, 46(3), 95-106.

Muniz, A. M., Norris, T., \& Fine, G. A. (2014). Marketing artistic careers: Pablo Picasso as brand manager. European Journal of Marketing, 48(1/2), 68-88.

Penet, P., \& Lee, K. (2014). Prize \& price: The turner prize as a valuation device in the contemporary art market. Poetics, 43, 149-171.

Peterson, K. (1997). The distribution and dynamics of uncertainty in art galleries: A case study of new dealerships in the Parisian art market, 1985-1990. Poetics, 25(4), 241-263.
Phillips, M., \& O’Reilly, D. (2007). Major case study: Rethinking tate modern as an art museum 'brand'. In R. Rentschler \& A. M. Hede (Eds.), Museum marketing (pp. 186-191). Oxford, UK: Elsevier.

Preece, C. (2015). The authentic celebrity brand: Unpacking Ai Weiwei's celebritised selves. Journal of Marketing Management, 31(5/6), 616-645.

Preece, C., \& Kerrigan, F. (2015). Multi-stakeholder brand narratives: An analysis of the construction of artistic brands. Journal of Marketing Management, 31(11-12), 1207-1230.

Preece, C., Kerrigan, F., \& O’Reilly, D. (2016). Framing the work: The composition of value in the visual arts. European Journal of Marketing, 50(7/8), 1377-1398.

Reckhenrich, J., Anderson, J., \& Kupp, M. (2009). The shark is dead: How to build yourself a new market. Business Strategy Review, 20(4), 40-47.

Rentschler, R. (2007). Museum marketing: No longer a dirty word. In R. Rentschler \& A. M. Hede (Eds.), Museum marketing (Vol. 1, pp. 12-18). Oxford, UK: Elsevier.

Rodner, V. L., \& Kerrigan, F. (2014). The art of branding-lessons from visual artists. Arts Marketing: An International Journal, 4(1/2), 101-118.

Rodner, V. L., Omar, M., \& Thomson, E. (2011). The brand-wagon: Emerging art markets and the Venice Biennale. Marketing Intelligence \& Planning, 29(3), 319-336.

Rodner, V. L., \& Preece, C. (2015). Painting the Nation: Examining the intersection between politics and the visual arts market in emerging economies. Journal of Macromarketing, 36(2), 128-148.

Rodner, V. L., \& Thomson, E. (2013). The art machine: dynamics of a value generating mechanism for contemporary art. Arts Marketing: An International Journal, 3(1), 58-72.

Samdanis, M., \& Lee, S. H. (2019). Uncertainty, strategic sensemaking and organisational failure in the art market: What went wrong with LVMH's investment in Phillips auctioneers? Journal of Business Research, 98, 475-488.

Sargeant, A. (1999). Marketing management for nonprofit organisations (pp 37-39). Oxford, UK: Oxford University Press.

Schroeder, J. E. (2005). The artist and the brand. European Journal of Marketing, 39(11/12), 1291-1305.

Stake, R. E. (1994). Case studies. In N. K. Denzin \& Y. S. Lincoln (Eds.), Handbook of qualitative research (pp. 236-247). Thousand Oaks, CA: Sage.

Thompson, D. (2008). The $\$ 12$ million stuffed shark: The curious economics of contemporary art. London, UK: Aurum Press.

Thorpe, V. (2012, March 10). Damien Hirst outlines vision for gallery to house his personal collection. The Guardian. Retrieved from https://www.theguardian.com/artanddesign/2012/mar/11/ damien-hirst-skull-tate-gallery 